\title{
KOMITMEN PROFESIONALISME GURU BERSERTIFIKASI DALAM PEMBELAJARAN (Studi Kasus pada Guru Madrasah Kota Jambi)
}

\author{
M. Syahran Jailani \\ Institut Agama Islam Negeri (IAIN) Sulthan Thaha Saifuddin Jambi, Indonesia \\ m.syahran@ymail.com
}

\begin{abstract}
The purpose of this research is to reveal the commitment of the professional teachers (civil servant) who teach in a private madrassa in Jambi to enhance the performance of instructional process. The research informants include civil servant teachers teaching in several private madrassa in Jambi. This qualitative research employs phenomenologist approach, referring to eleven steps by Spradley (1980). The research exemplifies that the professionalism of civil servant teachers at Jambi needs advancing. Although the teachers recognize some obstacles, they realize the commitment and responsibility as the professional teacher is essential to improve the instruction and selfquality. Secondly, it is found that the governments at Jambi do less-optimum efforts to elevate the professionalism of certificated-teachers. Then, the supervisions through education and training (Diklat) have not been well-socialized and the activities of pursuing Master degree program remain incidental. The agenda of teacher network (MGMP), Teacher Working Group (KKG) and School Principal Working Groups (KKKS) are not routinely conducted. Besides, the coordination obstacle among stakeholders is a major problem for the professionalism. The classical problem about funding also comes from the stakeholders in determining policy. Consequently, the policy about certified teachers and their development to support the educational process must be properly established.
\end{abstract}

Keyword: Professional teacher; commitment; responsibility Copyright (c) 2016 Madrasah Jurnal Pendidikan dan Pembelajaran Dasar. All Right Reserved

\section{A. Pendahuluan}

Undang-Undang Sistem Pendidikan Nasioanl Nomor 20 tahun 2003 Bab III Pasal 4, tentang prinsip-prinsip penyelenggraan pendidikanyang berbunyi, sebagi berikut; (1) pendidikan diselenggarakan secara demokratis dan berkeadilan serta tidak diskriminatif dengan menjunjung tinggi hak asasi manusia, nilai keagamaan, nilai kutural, dan kemajemukan bangsa; (2) pendidikan diselenggarakan sebagai satu kesatuan yang sistemik dengan sistem terbuka dan multimakna; (3) pendidikan diselenggarakan sebagai suatu proses pembudayaan dan pemberdayaan peserta didik yang berlangsung sepanjang hayat; (4) pendidikan diselenggarakan dengan memberi keteladanan, membangun kemauan, dan mengembangkan kreativitas peserta didik dalam proses pembelajaran; (5) pendidikan diselenggarakan dengan mengembangkan budaya membaca, menulis, dan berhitung bagi segenap warga masyarakat; dan (6) pendidikan diselenggarakan dengan memberdayakan semua komponen masyarakat melalui peran serta dalam penyelenggaraan dan pengendalian mutu layanan pendidikan

Vol. 9 No. 1, Desember 2016

Madrasah homepage: http://ejournal.uin-malang.ac.id/index.php/madrasah/index 
Prinsip-prinsip pendidikan di atas menuntut keterlibatan guru untuk melakukan proses pembelajaran dengan baik dan memberikan makna yang dalam pada diri peserta didik terutama anak-anak di sekolah. Karena guru tidak hanya sekedar transfer pengetahuan kepada peserta didik (anak), lebih dari itu guru juga diharapakan memberi konstribusi yang bermakna bagi kepribadian peserta didik, ini seiring pemikiran Van Scotter, J. Kraft dan D. Haas (1979) di mana fungsi guru di sekolah, yaitu; (1) eduacation (including not only knowledge and skill, but also attitudes, values, and sensiblities, (2) social role selection (including not only the highly visible act of certification but also the more subtle forms of sorting and selecting, (3) indoctrination, (4) custodial care, and (5) community activity.

Guru sebagai pendidik merupakan kunci sentral (central key) untuk bertanggung jawab penuh atas pelaksanaan proses pembelajaran bagi peserta didiknya di sekolah. Hal ini mengingat guru adalah orang pertama yang terdekat dalam keseharian anak dalam proses pembelajaran. Ia menjadi operator pembelajaran sekaligus juga sebagai sutradara terhadap keberhasilan sebuah proses keberhasilan anak sebagai peserta didik. Performa profesionalisme guru yang kompeten sangat dituntut dalam melaksanakan tugas dan fungsinya sebagai agen perubahan (change of agent) pada kehidupan pembelajaran peserta didik di sekolah serta di masyarakat dimana anak hidup dan bergaul dalam komunitasnya. Esensi dari proses pembelajaran bagi profesionalisme guru akan memberikan pengaruh nyata, tatkala dalam keseharian peserta didik, anak dapat memperoleh hasil belajar, kemudian memahami dan menerapkannya dalam kehidupan belajar sehari-hari peserta didik.

Menurut Prayitno (2008) kegiatan pendidikan yang digerakkan oleh energi yang secara laten ada di dalam diri guru dan peserta didik serta pada kondisi lingkungan harus menjadi kekuatan yang dapat memberi efek positif. Karenanya, tugas utama guru sebagai pendidik adalah upaya mengaktifkan, mensinergikan, mengharmonisasikan energi-energi yang ada menjadi kekuatan pendidikan yang terwujud dalam bentuk energi pembelajaran untuk mencapai tujuan pendidikan. Untuk mendukung terwujudnya kekuatan pendidikan yang terjadi di dalam interaksi antara guru sebagai pendidik dengan peserta didik pada proses pembelajaran dapat teraktualisasikan melalui energi pembelajran didukung dua pilarnya, yaitu pilar "kewibawaan", yang terdiri dari, yaitu; (1) pengakuan, 2) kasih sayang dan kelembutan, (3) pengarahan, (4) tindakan tegasa yang mendidik, dan (5) keteladanan dan pilar "kewiyataan", yang terdiri dari, yaitu; (1) kurikulum, (2) metode pembelajaran, (3) alat bantu pembelajaran, (4) lingkungan pembelajaran, (5) penilaian hasil pembelajaran (Prayitno, 2009).

Secara tegas,Undang-UndangNomor 20 tahun 2003Pasal 39 menyatakan tugas dan kewajiban guru yang yaitu merencanakan pembelajaran, melaksanakan pembelajaran, menilai pembelajaran, melakukan pembimbingan, melakukan pelatihan, melakukan penelitian hasil, dan melakukan pengabdian masyarakat. Selanjutnya Undang-Undang Republik Indonesia (RI) Nomor 14 tahun 2005 tentang Guru dan Dosen Bab 1 Pasal 1 ayat 1 menyatakan bahawa "Guru adalah pendidik profesional dengan tugas utama mendidik, mengajar, membimbing, mengarahkan, melatih, menilai, dan mengevaluasi peserta didik pada pendidikan anak usia dini jalur pendidikan formal, pendidikan dasar, dan pendidikan menengah." Ayat 4 menegaskan bahwa profesional adalah pekerjaan atau kegiatan yang dilakukan oleh seseorang dan menjadi sumber penghasilan kehidupan yang memerlukan keahlian, kemahiran, atau kecakapan yang memenuhi standar mutu atau norma tertentu serta memerlukan pendidikan profesi.

Sebagai guru proefsional, maka seorang guru mesti memiliki kompetensi yang menurut Undang-Undang Nomor 14 tahun 2005 tentang Guru dan Dosen ayat 10

Vol. 9 No. 1, Desember 2016

Madrasah homepage: http://ejournal.uin-malang.ac.id/index.php/madrasah/index 


\section{MADRASAH}

Jurnal Pendidikan dan Pembelajaran Dasar

p ISSN: 1979-5599 | e ISSN: 2502-194X

P a g e

menyatakan bahwa kompetensi adalah seperangkat pengetahuan, keterampilan, dan perilaku yang harus dimiliki, dihayati, dan dikuasai oleh guru atau dosen dalam melaksanakan tugas keprofesionalan. Peraturan Pemerintah Nomor 19 tahun 2005 tentang Standar Nasional Pendidikan Bab VI Standar Pendidik dan Tenaga Kependidikan Bagian Kesatu Pendidik Pasal 28 ayat 1 menyatakan bahwa pendidik harus memiliki kualifikasi akademik dan kompetensi sebagai agen pembaharuan, sehat jasmani dan rohani, serta memiliki kemampuan untuk mewujudkan tujuan pendidikan nasional. Ayat 3, menyebutkan kompetensi sebagai agen pembelajaran pada jenjangpendidikan dasar dan menengah serta pendidikan anak usia dini meliputi: (a) kompetensi pedagogik; (b) kompetensi kepribadian; (c) kompetensi profesional; (d) kompetensi sosial.

Selain itu, pada Undang-Undang Guru dan Dosen Nomor 14 tahun 2005 Pasal 1 ayat 11 dan 12, menegaskan bahwa sertifikasi adalah proses pemberian sertifikat pendidik untuk guru dan dosen. Sertifikat pendidik adalah bukti formal sebagai pengakuan yang diberikan kepada guru dan dosen sebagai tenaga profesional.Dan bagi guru-guru yang bersertifikasi, diberi gaji dan penghasilan sebagai tugas keprofesionalannya. Sebagaimana ayat 15 dan 16, menegaskan bahwa gaji adalah hak yang diterima oleh guru atau dosen atas pekerjaannya dari penyelenggara pendidikan atau satuan pendidikan dalam bentuk finansial secara berkala sesuai dengan peraturan perundang-undangan. Penghasilan adalah hak yang diterima oleh guru atau dosen dalam bentuk finansial sebagai imbalan melaksanakan tugas keprofesionalan yang ditetapkan dengan prinsip penghargaan atas dasar prestasi dan mencerminkan martabat guru atau dosen sebagai pendidik profesional.

Hasil penelitian Khodijah (2013) mengungkapkan bahwa rata-rata kinerja guru pasca sertifikasi baiksecara keseluruhan maupun dilihat dari indikator perencanaan pembelajaran, pelaksanaan pembelajaran, dan pengembangan profesi menunjukkan kategori sedang, bahkan masih ada sebagian guru yang menunjukaan kinerja dalam kategori rendah. Artinya, kinerja guru setelah lulus sertifikasi dan mendapat tunjangan profesi masih berada di bawah standar minimum kinerja. Dengan demikian, dapat dikatakan bahwa pelaksanaan program sertifikasi yang digelontorkan pemerintah dengan dana yang tidak sedikit tidak membuat kinerja para guru menjadi optimal.

Hari ini, telah ribuan bahkan ratusan ribu guru-guru RI telah menyandang status dengan gelar guru bersertifikasi, termasuk juga guru-guru yang bertugas di kota Jambi. Itu artinya, guru-guru kita yang lulus sertifikasi telah memiliki sebutan guru profesional dan diberikan tunjangan profesi pendidik dengan tambahan penghasilan satu kali gaji pokok plus gaji/penghasilan lain sesuai peraturan perundang-undangan yang berlaku. Dari kacamata penghasilan gaji guru-guru bersertifikasi telah lebih dari cukup, bahkan bagi guru-guru yang mengabdikan diri sebagi insan pendidik yang mengajar di daerah-daerah terpencil dan pedalaman, pemerintah memberikan pula tunjangan tambahan penghasilan.

Dilihat dari kinerja dan kualitas proses pembelajaran, apakah guru-guru bersertifikasi sudah menjalankan dan melaksanakan ketentuan-ketentuan sebagaimana Peraturan Menteri Pendidikan Nasional Republik Indonesia nomor 18 tahun 2007 tentang sertifikasi guru dalam jabatan, tujuan, dan fungsi serta manfaat dari pelaksanaan dan pengangkatan guru-guru bersertifikasi? mengapa pertanyaan ini muncul? sulit untuk menjawab secara pasti dari sudut mana indikator keberhasilan sertifikasi guru membawa perubahan pada kualitas pendidikan di Indonesia. Mengingat perjalanan program sertifikasi baru berjalan lima tahun sejak 2007 dengan berbagai perbaikan-perbaikan menuju penyempurnaan. Berbagai komentar miring, kurang mengenakan, menyudutkan

Vol. 9 No. 1, Desember 2016

Madrasah homepage: http://ejournal.uin-malang.ac.id/index.php/madrasah/index 
bahkan ada sekelompok orang yang menginginkan agar pemberian tunjangan penghasilan guru sertifikasi ditinjau ulang bahkan ada pula yang mengingin dihapuskan saja. Mengingat keberadaan sertifikasi guru tidak berkorelasi positif dengan peningkatan kualitas lulusan pendidikan kita terutama pada pendidikan dasar dan menengah maupun di madrasah-madrasah yang dikelola Kementerian Agama, atau dengan kata lain guruguru bersertifikasi yang memperoleh penghasilan tambahan sebesar gaji pokok tersebut tidak memberikan konstribusi, tidak memberi perubahan dari sisi proses pembelajaran, serta tidak sukses meraih capaian prestasi belajar peserta didik.

Penelitian ini bertujuan untuk mengungkapkan bagaimana usaha profesionalismeguru bersertifikasi dalam meningkatkan kualitas pembelajaran di madrasah, bagaimana pembinaan guru-guru bersertifikasi dalam meningkatkan kualitas pembelajaran di madrasah dan apa saja faktor penghambat dan pendukung profesionalisme guru bersertifikat dalam meningkatkan kualitas pembelajaran di madrasah.

\section{B. METODE PENELITIAN}

Penelitian ini dilakukan dengan menggunakan pendekatan kualitatif. Pendekatan ini dilakukan dalam rangka menemukan kebermaknaan dari setiap interaksi guru-guru PNS bersertifikasi sebagai pendidik profesional dengan peserta didik, interaksi guru dengan teman sejawat seprofesi, interaksi guru-guru dengan para stakeholders (Kemenag dan LPTK FITK IAIN STS Jambi). Langkah-langkah penelitian dikembangkan dengan berpedoman kepada pemikiran Spradley (1980).

Mengingat penelitian ini akan mengungkap secara khusus tentang guru-guru pegawai bersertifikasi yang mengajar di madrasah swasta kota Jambi dalam proses pembelajaran dan juga interaksi guru dalam situasi sosial, maka Bogdan dan Biklen (1982)menyarankan bahwa karakteristik penelitian dengan pendekatan kualitatif hendaklah mempertimbangkan hal-hal sebagai berikut, meliputi : (1) latar alamiah sebagai sumber data; (2) peneliti sebagai instrumen utama; (3) penelitian kualitatif lebih mementingkan proses daripada hasil; (4) penelitian dengan pendekatan kualitatif cenderung menganalisis data secara induktif.; dan (5) makna yang dimiliki pelaku mendasari tindakan-tindakan mereka merupakan aspek esensial dalam penelitian kualitatif.

Pengambilan sampel dalam penelitian ini mengacu pada kreteria yang digunakan Spradley (1980), yaitu: (1) subjek yang telah cukup lama dan intensif menyatu dengan suatu kegiatan atau medan aktivitas yang menjadi sasaran perhatian penelitian; (2) subjek yang masih terlibat secara penuh/aktif pada lingkungan kegiatan yang menjadi sasaran/perhatian penelitian; (3) subjek yang mempunyai cukup banyak waktu atau kesempatan untuk diminta informasi; (4) subjek yang dalam memberikan informasi tidak cendrung diolah atau dikemas terlebih dahulu; dan (5) subjek yang sebelumnya tergolong masih asing dengan peneliti sehingga dapat merasa lebih tertantang untuk belajar sebanyak mungkin dari subjek yang semacam guru baru bagi dirinya.

Metode pengumpulan data yang digunakan dalam penelitian ini sebagimana yang disarankan Denzin dan Lincoln (2009), yaitu observasi, wawancara, dokumentasi dan menggunakan sumber non manusia, serta pencatatan hasil pengumpulan data. Didukung pula oleh interaksi langsung dengan subjek peneliti seperti, mendengarkan, melihat, berbicara, bertanya, meminta penjelasan, mengekspresikan dan menangkap isyarat yang tersirat dari subjek yang terlibat.

Vol. 9 No. 1, Desember 2016

Madrasah homepage: http://ejournal.uin-malang.ac.id/index.php/madrasah/index 


\section{MADRASAH}

Jurnal Pendidikan dan Pembelajaran Dasar

p ISSN: 1979-5599 | e ISSN: 2502-194X

P a g e

Lincoln dan Guba (1985) menyatakan bahwa untuk menjaga kualitas hasil penelitian, data telah mengalami proses uji keabsahan data melalui: (1)standar kredibilitas;(2) standar tranferbilitas; (3) standar dependabilitas; dan (4) standar konfirmabilitas. Kualitas hasil penelitian sangat bergantung dari catatan data lapangan dan hasil observasi yang mendalam serta didukung rekaman yang dilakukan peneliti. Upaya mendapatkan standar ini, maka konsultan/supervisor penelitian ini sangat diharapkan oleh auditor.

Teknik analisis data yang digunakan dalam penelitian ini berpedoman kepadapendapat Spradley (1980), yaitu; (1) analisis domain (making a domain analysis). Teknik ini adalah suatu analisa untuk memperoleh gambaran dan pengertian yang bersifat umum dan relatif menyeluruh apa yang tercakup dalam fokus atau pokok permasalahan yang tengah diteliti. Jadi analisis domain ini merupakan usaha-usaha untuk mencari polapola perilaku tertentu pada situasi sosial, suatu proses untuk menemukan bagian-bagian atau unsure-unsur kawasan dari makna kultural yang mengandung kategori-kategori yang lebih kecil;(2) analisis taksonomi (taxonomy analysis). Analisis ini bertujuan untuk mencari atau menemukan hubungan-hubungan antar komponen dari masing-masing kawasan. Analisis ini menghasilkan suatu taksnonomis yang akan mendeskripsikan dan menjelaskan fenomena dari fokus peneltian; (3) analisis komponensial (componential analysisi).

Menurut Spradley (1980), bahwa analisis komponensial adalah suatu usaha untuk mencari secara sistematis komponen-komponen yang mengandung arti secara sistematis, yang berhubungan dengan kategori budaya. Agar dimensi-dimensi kontras dapat diidentifikasi, maka diajukan sejumlah pertanyaan kontras. Selanjutnya dengan pertanyaan kontras, sejumlah dimensi kontras dapat diidentifikasikan. Pencarian dimensi dari satu kategori dapat dilakukan dengan memasukkan atribut-atribut yang ditemukan kedalam bentuk format paradigm; dan (4) tema budaya (cultural theme). Berdasarkan analisis komponensial yang dilakukan, ditemukan tema budaya (discovering cultural theme).

\section{HASIL PENELITIAN DAN PEMBAHASAN}

Guru adalah sosok/figur yang melekat pada diri sesorang yang dimuliakan banyak orang. Kehadirannya di tengah-tengah kehidupan umat manusia sangat ditunggu, didambakan, bahkan diteladani oleh manusia lain untuk belajar, untuk mendapatkan sesuatu yang bermakna, bahkan mengembangkannya bagi peradaban umat manusia di muka bumi ini. Sulit dibayangkan jika di tengah-tengah kehidupan manusia tidak ada seorang guru yang dapat menuntun, membimbing, mengarahkan, melatih, mengajarkan dan mendidik manusia (Yamin, 2006).

Sosok guru dituntut memiliki keahlian tertentu tidak hanya sebatas ia memiliki performa yang disyaratkan, tetapi lebih dari itu karena guru sudah dianggap pekerjaan profesi yang dipandang menjanjikan banyak orang, tidak hanya karena pekerjaannya yang mulia. Tetapi juga suatu pekerjaan yang mampu mengangkat harkat dan martabat manusia dikemudian hari. Pekerjaan menjadi guru juga menuntut seseorang itu memiliki kreteria dan syarat-syarat khusus, mengingat tidak semua orang mampu melakoni pekerjaan ini sebagaimana diinginkan.

Berdasarkan hasil temuan penelitian, berkaitan dengan "Profesionalisme Guru Bersertifikasi (Studi Analsis Guru PNS yang mengajar di Madrasah Swasta Kota Jambi)" yang dikemas secara khusus berdasarkan rumusan masalah dengan fokus masalah yaitu; 1) apa saja usaha guru profesionalisme bersertifikasi dalam meningkatkan kualitas pembelajaran

Vol. 9 No. 1, Desember 2016

Madrasah homepage: http://ejournal.uin-malang.ac.id/index.php/madrasah/index 
di madrasah, 2) bagaimana pelaksanaan pembinaan guru-guru bersertifikasi dalam meningkatkan kualitas pembelajaran di madrasah, dan 3) apa saja faktor penghambat dan faktor pendukung guru profesionalisme bersertifikasi dalam meningkatkan kualitas pembelajaran.

\section{Upaya Profesionalisme Guru Bersertifikasi dalam Meningkatkan Kualitas Pembelajaran di Madrasah.}

Terungkap bahwa usaha guru profesional dalam meningkatkan kualitas pembelajaran di madrasah menghendakii komitmen yang tinggi dalam diri guru, tidak sekedar menjalankan tugas dan kewajiban yang melekat dalam diri guru, karena yang bersangkutan bertugas sebagai guru. Komitmen itu diwujudkan dalam tindakan nyata dan aktivitas seharian guru.

Usaha guru dalam meningkatkan profesionalisme hendaknya dimulai dari guru itu sendiri. Sebagai guru bersertifikasi, berusaha untuk meningkatkan profesionalisme dengan mengikuti kegiatan-kegiatan yang dilaksanakan oleh guru-guru dari sekolah lain, melalui kegiatan MGMP (Musyawarah Guru Mata Pelajaran) yang dilaksanakan oleh guru dari lingkungan Dinas Pendidikan dan Kebudayaan. Komunikasi dan bangunan silaturrahmi antar guru-guru madrasah dan dari sekolah-sekolah di lingkungan kementerian Pendidikan dan kebudayaan, menjadi penting untuk mendapatkan informasi. Hal ini penting, agar kita tidak keringgalan informasi, dan biasanya informasi dari Kementerian Agama seringkali terlambat dii terima guru-guru. (Wawancara, 26 Juni 2013. pukul 13.00 WIB).

Peningkatkan kualitas pembelajaran di madrasah bagii profesionalisme guru bersertifikasi, memang sudah menjadi kewajiban seorang guru, terlebih bagai guru bersertfikasi. Ada beban yang lebih tidak sekedar tugas dan tanggung jawab, karena di balik status guru bersertifikasi ada penghargaan yang diberikkan pemerintah berupa tunjangan penghasilan tambahan satu kali gaji pokok guru. Kenyataan ini sudah selayaknya guru berusaha meningkatkan berbagai cara agar sebagai gurtu professional yang bersertifikasi tidak dipertanyakan banyak orang (Wawancara, 26 Juni 2013).

"Kualitas guru sangat tergantung diri kita sendiri, maukah kita belajar, mencari pengalaman sebanyak-banyak, bertanya, bahkan tidak sungkan-sungkan berdialog dengan teman-teman guru yang lain, bertukar informasi. Kita pun harus mau membuka diri atas segala kekurangan yang kita miliki. Jujur sajalah, saya sekalipun guru bersertifikasi menyadari bahwa masih banyak kekurangan yang saya miliki, contoh sederhana saja kelemahan kita dalam mengakses informasi di media masa intenet. Terkadang kita gagap teknologi (gaptek) juga. Padahal salah satu untuk meningkatkan kwalitas pembelajaran di kelas yang mestinya dilakukan guru adalah mengajar dengan memanfaatkan technology. Nyatanya masih banyak juga diantara tteman-teman gutu yang belum mampu mengakses informasi melalui media yang ada" (Wawancara, 28 Juni 2013, pukul 13.00 WIB).

Senada dengan pendapat guru MTs Labor, guru MTs Tarbiyah Islamiah, juga menyatakan, sebagai berikut:

"Saya telah 2 tahun memperoleh tunjangan sertifikasi, secara materi penghasilan saya sebagai guru memiliki tambahan cukup lumayan. Saya sadar bahwa di pundak saya ada tanggung jawab yang harus saya jalankan sebagai guru bersertifikasi, saya berkewajiban untuk mengajar minimal 24 jam dalam seminggu sesuai dengan aturan yang di berlakukan. Untuk itu saya berusaha memenuhi kewajiban mengajar 24 jam tersebut, sekalipun di MTs Tarbiyah Islamiyah, lokal terbatas yang mengakibatkan jam pelajaran juga terbatas, maka guru-guru bersertifikasi berusaha untuk memenuhinya dengan

Vol. 9 No. 1, Desember 2016

Madrasah homepage: http://ejournal.uin-malang.ac.id/index.php/madrasah/index 


\section{MADRASAH}

Jurnal Pendidikan dan Pembelajaran Dasar

p ISSN: 1979-5599 | e ISSN: 2502-194X

P a g e

menambah kegiatan lain, seperti menjadi wali kelas, menjadi wakil kepala madrasah, atau menjadi Pembina kegiatan siswa seperti Pembina pramuka, Pembina UKS. Usaha untuk meningkatkan kwalitas diri guru tentu dengan memperbanyak komunikasi dengan sesama guru. Harus diakui untuk guru-guru di lingkungan Kementerian Agama Kota Jambi, memang sangat terbatas sekali usaha-usaha meningkatkan kualitas guru bersertifikasi. Jika pun ada hanya guru-guru madrasah negeri, sementara guru madrasah swasta sering kali, jika guru madrasah negeri tidak ada. Barulah guru madrasah swasta diberi kesempatan untuk mengikiti kegiatan". (Wawancara, 29 Juni 2013, pukul 17.00 WIB).

Dari pengamatan penulis di lapangan, dari beberapa lokasi penelitian terutama berkaitan dengan guru PNS yang bersertfikasi mengajar di madrasah swasta kota Jambi, di akui bahwa masih belum menujukkan peningkatann kualitas mengajar sebagaimana yang diharapkan ini terlihat dari misalnya: persiapan perangkat pembelajaran (RPP), silabus persemester, RPP tahunan yang memerlukan kesempurnaan, buku-buku pegangan mengajar yang hanya terbatas pada buku pegangan guru itu saja, tidak memiliki referensi tambahan di luar buku pegangan, media yang dipersiapkan sebatas apa yang ada dalam buku saja, media tidak dikembangkan dengan mengadopsi kemajuan teknologi (Wawancara, 28 Juni 2013, pukul 17.00 WIB).

"Seharusnya memang kami guru bersertifikasi ini harus meningkatkan kualitas diri melalui persiapan kemampuan mengajar yang lebih terasah lagi melalui pemanfaatan kemanjuan teknologi dan media yang tersedia. Kemudian persiapan perangkat pembelajaran yang lebih lengkap mulai dari persiapan konten (materi) pelajaran, analisis materi, analisis kisi-kisi soal, sampai kepada persiapan diri ketika mengajar. Mengapa persiapan diri menjadi penting, karena siswa akan melihat penampilan kita (guru) dengan seksama manakala kita sedang mengajar, mereka akan tau jika kita kurang dalam persiapan mengajar. Karena anak-anak kita hari ini lebih memiliki pengetahuan tidak sekedar apa yang dia dapat di kelas, tetapi juga mereka sudah memiliki pengalaman/pengetahuan yang mungkin diakses melalui internet. Oleh karena itu saya sering mengingatkan kepada guru-guru yang telah memperoleh status guru bersertifikasi untuk selalu meningkatkan kemampuan mengajar, tidak bosan-bosan untuk belajar dengan guru-guru yang sudah memiliki kemampuan mengajar, atau sering-sering mencari informasi yang mendukung potensi kemampuan. Dan kalah penting juga menjaga performance (penampilan) diri setiap hari, agar tetap memberikan rasa senang pada diri peserta didik. (Wawancara. Tanggal, 01 Juli 2013, pukul 12.30 WIB).

Senada dengan Kepala MTs Azas Islamiyah, hal yang sama juga dikemukakan oleh Kepala MTs Labor Fakultas Tarbiyah, bahwa:

"Sebagai guru berstatus bersertifikasi, saya sering mengingatkan kepada guu-guru tersebut untuk meningkatkan kualitas diri dalam rangka meningkatkan kualitas pembelajaran di kelas, pemerintah berusaha memberikan yang terbaik untuk guru-guru kita supaya ada kemajuan pendidikan di Indonesia, hanya terkadang saya melihat masih ada juga guru-guru ini menganggap biasa-biasa saja. Padahal mereka sudah menerima tunjungan penghasilan sebagai guru bersertifikasi setiap bulan. Mestinya ada hubungan positif satu pengaruh signifikan antara penambahan gaji dengan kualitas pembelajaran anak-anak. Saya melihat belum optimal usaha guru-guru bersertifikasi ini dalam meningkatkan kualitas pembelajaran di kelas. Model-model mengajar dengan pendekatan guru yang dominan dalam menjagar ketimbang siswa yang aktif, atau guru-guru masih

Vol. 9 No. 1, Desember 2016

Madrasah homepage: http://ejournal.uin-malang.ac.id/index.php/madrasah/index 
terpaku menggunakan media yang ada berupa papan tulis, buku paket dan sangat sedikit sekali memanfaatkan media technology semisal internet misalnya. Saya tidak tau apakah mereka menyadari posisi mereka hari sebagai guru bersertikasi dan tuntutan duniapendidikan hari ini, mengingat setiap hari aktivitas mereka bagi yang bersertifikasi hanya mengajar dan mengajar. Tanpa mau mencari dan menambah pengalaman dengan kegiatan-kegiatan di luas sekolah seperti terlibat kegiatan komunitas pendidikan." (Wawancara, 03 Juli 2013. Pukul 13.00 WIB).

Kenyataan ini telah menjadi pemikiran kepala madrasah MTs Labor, bagaimana supaya guru-guru bersertifikasi terus meningkatkan profesionalisme. Agar kualitas pembelajaran terus memproleh hasil yang terus meningkat. Mengingat tuntutan dan tanggung jawab guru bersertifikasi. Pemerintah dalam hal ini baik Kementerian Pendidikan dan Kebudayaan maupun Kementerian Agama terus berupayan menggagas berbagai kegiatan untuk meningkatkan kualitas guru bersertifikasinya, misalnya dilingkungan Kementerian Pendidikan dan Kebudayaan, begitu pula dilingkungan Kemeneterian Agama dilakukan pembuatan laporan kinerja guru(LKG), yang berisi perangkat laporan seluruh aktivitas guru selama mengajar setelah ditetapkan sebagai guru bersertifikasi. (Wawancara, 04 Juli 2013. Pukul 12.00 WIB).

\section{Pembinaan Guru-Guru Bersertifikasi}

Pembinaan guru-guru bersertifikasi adalah keharusan yang mesti dilaksanakan oleh stakeholders. Berdasarkan Undang-Undang Guru dan Dosen nomor 14 tahun 2005, dan Peraturan Pemerintah Nomor 19 Tahun 2005 tentang Standar Nasional Pendidikan, Bab VI berkaitan dengan Standar Pendidik dan Tenaga Kependidikan, guru yang telah lulus sertifikasi baik secara prosedur portofolio maupun lulus melalui pendidikan dan pelatihan dianggap cakap dan memiliki status guru profesional dan diberi penghasilan tambahan.

Namun, melalui pengamatan penulis di lapangan, pembinaan bagi guru-guru bersertifikasi terutama di madrasah swasta, ternyata masih jauh dari harapan. Dari penelusuran dan wawancara penulis dengan beberapa kepala madrasah dan beberapa guru-guru yang bersertifikasi, hingga detik ini menurut pengamatan guru-guru belum ada model/ pola pembinaan yan betul-betul terorganisir dengan baik bagi guru-guru bersertifikasi. Mestinya pemerintah sudah memikirkan ke arah itu, agar guru-guru bersertifikasi tersebut terus dalam pembinaan. Pembinaan yang dimaksud adalah pembinaan yang mengarah dan mengasah kemampuan para guru-guru agar terampil dan memiliki kemampuan yang lebih, tidak sekedar apa yang di alami guru-guru saat ini.

Kemampuan guru-guru bersertifikasi madrasah swasta, itu misalnya: inisiatif/inovatif dalam mengajar memberikan kepuasan pada diri pesera didik, memiliki komitmen dalam hal memperbaiki kualitas diri, dan lain-lain. Jika pun ada, misalnya pelatihan yang dilaksanakan Fakultas Ilmu Tarbiyah dan Keguruan IAIN Sulthan Thaha Saifuddin Jambi, sebagian besar peserta adalah guru-guru yang di data belum memperoleh sertifikasi. Adapun, tagihan dari Kementerian Agama Kota Jambi yang dilakukan berupa Laporan Kinerja Guru (LKG) bukan pola pembinaan, tapi itu berupa kertas kerja yang memang sudah menjadi kewajiban guruguru untuk dilaporkan kepada pemangku kebijakaan. Pemerintah, dalam hal ini apakah kementerian Pendidikan Nasional maupun Kementerian Agama sudah memiliki konsep yang jelas pola pembinaan untuk guru-guru bersertifikasi. (Wawancara, 03 Juli 2013. Pukul 13.00 WIB).

Kesempatan untuk memperoleh pembinaan melalui jenjang pendidikan dan pelatihan bagi guru-guru bersertifikasi yang mengajar di madrasah khususnya madrasah swasta terbilang

Vol. 9 No. 1, Desember 2016

Madrasah homepage: http://ejournal.uin-malang.ac.id/index.php/madrasah/index 


\section{MADRASAH}

Jurnal Pendidikan dan Pembelajaran Dasar

p ISSN: 1979-5599 | e ISSN: 2502-194X

P a g e

jarang diperoleh. Seharusnya kesempatan untuk memperoleh pembinaan dalam rangka peningkatan kualitas guru bagi guru-guru bersertifikasi hendaknya sudah menjadi hak masing-masing guru. Jika pun ada guru-guru yang ingin meningkatkan kualitas, umumnya atas inisiatif sendiri para guru. Misalnya mengikuti program S2 baik di IAIN Sulthan Thaha saifuddin Jambi, melalui program S2 Universitas Jambi atau program S2 di luar Kota Jambi, seperti yang di ungkapkan guru MTs Tarbiyah Islamiyah. (Wawancara, 03 Juli 2013. Pukul 13.30 WIB).

\section{Pembinaan melalui Pendidikan dan Pelatihan (Diklat)}

Pembinaan guru-guru bersertifikasi melalui pendidikan dan pelatihan secara berkelanjutan dilakukan oleh pemangku kebijakan secara terencana dan terorganisir melalui kebijakan yang sudah disusun berdasarkan hasil pemetaan yang dianggarkan melalui dana baik APBN maupun APBD. Seperti Kementerian Pendidikan Nasional maupun Kementerian Agama Republik Indonesia, di lingkup Kementerian Agama Republik Indonesia beberapa kegiatan pelatihan dilakukan setiap tahun, seperti tahun 2012 ini dilakukan Pelatihan Peningkatan KompetensiGuru (PKG) Kerjasama Direktur Pendidikan Agama Islam(PAI) Direktorat Jenderal Pendidikan Islam Kementerian Agama RI dengan Fakultas Ilmu Tarbiyah dan keguruan IAIN Sulthan Thaha Saifuddin Jambi sebagai pelakasana teknis, dengan peserta guru-guru yang telah mengikuti sertifikasi pada tahun yang sama. Secara detail penulis belum mengetahui unsur-unsur dari mana saja para peserta pelatihan yang berlangsung sejak tangal 29 November 2012 sampai dengan tanggal 17 Desember 2012. Dari buku pedoman petunjuk pelaksanaan Peningkatan Kompetensi Guru (PKG) tahun 2012, peserta terdiri dari guru-guru Pendidikan Agama Islam (PAIS) Sekolah Dasar dan guru-guru Pendidikan Agama Islam (PAIS) Sekolah Menengah Pertama (SMP) dan Sekolah Menengak Kejuruan (SMK).

Pelatihan Peningkatan Kompetensi Guru (PKG) tahun 2012 dan 2013, misalnya dari tujuan yang ingin dicapai adalah sebagai berikut: 1) meningkatkan skill guru Pendidikan Agama Islam dalam konteks pelaksanaan pembelajaran sehingga memiliki kemampuan dan komitmen tinggi dalam penyelenggaraan PAI di sekolah, 2) meningkatkan kemampuan dan wawasan guru terhadap content/materi sehingga memiliki kedalaman pemahaman mengembangkan content/materi pendidikan agama islam,dan 3) meningkatkan kemampuan GPAI dalam menciptakan budaya sekolah (Culture School) yang kondusif bagi terbinanya kemampuan peserta didik yang dapat mengintegrasikan agama, baik dalam hal pemahaman, penghayatan maupun perilaku sehari-gari. Sedangkan target yang ingin diharapkan dari pelaksanaan PKG ini adalah: 1) mampu merangcang dan mengembangkan bahan ajar pembelajaran PAI yang kontekstual, 2) mampu melakukan inovasi pembelajaran PAI melalui penerapan pembelajaran PAIKEM, dan 3) mampu mengembangkan media pembelajaran PAI melalui TIK. (lihat Pedoman PKG tahun 2012: 2-3) dan (Wawancara, 28 November 2013. Pukul, 09.30 WIB).

Ketika penulis melakukan wawancara dengan guru-guru madrasah swasta yang telah lulus sertifikasi tahun 2010 dan 2011 dari Kementerian Departemen Agama Kota Jambi, dan mempertanyaan kegiatan Peningkatan Kompetensi Guru (PKG) tahun 2012 yang dilaksanakan oleh Fakultas Tarbiyah IAIN Sulthan Thaha Saifuddin Jambi. Guruguru tersebut memiliki hasrat dan keinginan yang kuat untuk mengikuti kegiatan dimaksud, mengingat selama kurang lebih dua tahun ini, kami yang telah lulus guru sertifikasi belum mendapat pelatihan. Guru-guru sangat senang sekali jika memang ada

Vol. 9 No. 1, Desember 2016

Madrasah homepage: http://ejournal.uin-malang.ac.id/index.php/madrasah/index 
kegiatan Peningkatan Kompetensi Guru (PKG) di peruntukan bagi guru-guru lulus sertifikasi, terutama bagi guru-guru di lingkungan Kementerian Agama. Guru-guru merespon dengan positif, bahkan sangat berharap jika pun belum memperoleh kesempatan tahuni ini, mudah-mudahan tahun depan ada kegiatan sejenis ini. Guna menambah pengalaman dan untuk mengetahui sejauhmana guru-guru yang telah disertifikasi ini memiliki kemajuan atau sebaliknya. Saya pun berharap, kegiatan PKG ini dapat terlaksana untuk guru-guru di lingkungan kementerian Agama. Jangan hanya untuk guru-guru yang mengajar di lingkungan Kementerian Pendidikan Nasional saja PKG ini dilaksanakan dan kami berharap betul tahun depan pelatihan ini bisa terlaksana". (Wawancara, 29 November 2013. Pukul, 19.30 WIB).

\section{Pembinaan melalui Musyawarah Kerja Kepala Sekolah (MKKS), Musyawarah Guru Mata Pelajaran (MGMP), Kelompok Kerja Guru (KKG)}

Selain pembinaan guru-guru bersertifikasi melalui kegaiatan pelatihan dan pendidikan yang diselenggarakan secara terprogram seperti di atas, beberapa kegiatan pembinaan peningkatan kualitas guru dapat dilaksanakan melalui kegiatan Musyarawarah Kerja Kepala Sekolah (MKKS), Musyawarah Guru Mata Pelajaran (MGMP) maupun melalui Kelompok Kerja Guru (KKG).

Pengamatan penulis dan wawancara langsung, dengan beberapa Kepala MTs maupun guru-guru terungkap, misalnya menurut Kepala MTs Azas Islamiyah, bahwa: sebagai Kepala Madrasah, jarang sekali kegiatan Musyarwarah Kerja Kepala Sekolah hampir tidak ada.

"Mestinya secara berkala dan rutin kegiatan ini harus dilaksanakan, tentu di fasilitasi oleh Kementerian Agama Kota Jambi. Karena banyak hal bisa dibicarakan antar Kepala Madrasah, jika pun ada pertemuan antar kepala madrasah biasanya undangan di luar agenda resmi Kepala Madarasah. Momen ini biasanya kami manfaatkan untuk berbagai pengalaman dengan kepala sekolah lain, termasuk mencari informasi berkitan dengan sertifikasi guru. Karena tidak secara khusus dibahas antar Kepala Mardasah, tentang sertifikasi guru, terkadamg persoalan sertifikasi yang seharusnya memerlukan pembahasan mendalam tidak menjadi tuntas penyelesaiannya. Dari informasi yang di peroleh, tidak dilaksanakannya MKKS alasannya sederhana tidak ada anggaran untuk kegiatan dimaksud."(Wawancara, 04 Juli 2013. Pukul, 12.00 WIB).

Idealnya, MGMP dapat berfungsi sebagai wahana dan media yang efektif bagi guru-guru untuk bermusyawarah dan berdiskusi banyak hal, tidak hanya soal-soal proses pembelajaran di kelas, tetapi juga berkaitan dengan pribadi guru, kompetensi guru dan nilai-nilai keprofesian seorang guru alam berkiprah di masyarakat diman mreka tinggal bahkan dalam masyarakat dunia. Dalam banyak pelajaran berkitan dengan MGMP, di beberapa tempat (di luar provinsi Jambi) justru MGMP menjadi ajang tempat bagi guruguru untuk mengemukakan pendapat, argumentasi, bahkan keluhan pribadi tentang keberadaan mereka di tengah persoalan pendidikan yang semakain hari, semakin menuntut keprofesionalan guru-guru, apalagi guru yang telah menyandang predikat guru bersertifikasi. Banyak hal yang harus dilakukan, mengingat tuntutan guru bersertifikasi di harapkan adanya perubahan mendasar pendidikan kita di tanah air Indonesia.

Undang-Undang Guru dan Dosen nomor 14 tahun 2005, dan Peraturan Pemerintah nomor 19 tahun 2005 mengamanatkan agar seorang guru profesional berpendidikan minimal S-1/D-4 dan berkompetensi sebagai agen pembelajaran yang di buktikan dengan kepemilikan sertifikat pendidik setelah dinyatakan lulus uji kompetensi. Atas profesinya tersebut, guru yang bersangkutan berhak mendapatkan imbalan (reward) berupa tunjangan profesi dari pemerintah sebesar satu kali gaji pokok. Dan Undang-undang dan

Vol. 9 No. 1, Desember 2016

Madrasah homepage: http://ejournal.uin-malang.ac.id/index.php/madrasah/index 


\section{MADRASAH}

Jurnal Pendidikan dan Pembelajaran Dasar

p ISSN: 1979-5599 | e ISSN: 2502-194X

P a g e

Peraturan Pemerintah tersebut tergambar secara jelas bahwa faktor pendukung profesionalisme guru bersertifikasi dalam meningkatkan kualitas pembelajaran, yaitu: 1) Undang-undang yang mewajibkan guru profesional minimal S-1/D-4, 2) Gaji/Tunjangan Tambahan, 3) Pengabdian karena masa kerja.

Setiap aktivitas yang memerlukan keterlibatan manusia sebagai subjek dalam kegiatan, biasanya faktor yang penghambat senantiasanya menyertainya. Sama halnya dengan upaya profesionalisme guru-guru bersertifikasi dalam meningkatkan kualitas pembelajaran. Hambatan-hambatan kearah hal demikian tersebut sudah menjadi perhatian serius. Penulis, dari hasil wawancara dan observasi terungkap bahwa penghambat utama dalam rangka profesinalisme guru-guru bersertifikasi dalam meningkatkan kualitas pembelajaran di madrasah, sebagai berikut: 1). Koordinasi. Koordinasi antar guru-guru bersertifikasi dirasakan sangat lemah. Koordinasi antar Kepala Madrasah juga tidak terjalin dengan baik. Komunikasi antar stakeholder dengan para guru dan Kepala Madrasah tidak sebagaimana diharapkan. 2) Pendanaan. Persoaalan klasik senantiasa menghampiri aktivitas manusia, pendanaan menjadi alasan utama mengapa kemudian kegiatankegiatan yang mengarah pada peningkatan kualitas pendidikan menjadi kendala, termasuk upaya peningkatan profesionalisme guru sering kali mengalami hambatan.

\section{Pembahasan}

Guru adalah sosok/figur yang melekat pada diri sesorang yang dimuliakan banyak orang. Kehadirannya di tengah-tengah kehidupan umat manusia sangat ditunggu, didambakan, bahkan diteladani oleh manusia lain untuk belajar, untuk mendapatkan sesuatu yang bermakna, bahkan mengembangkannya bagi peradaban umat manusia di muka bumi ini. Sulit dibayangkan jika di tengah-tengah kehidupan manusia tidak adanya seorang guru yang dapat menuntun, membimbing, mengarahkan, melatih, mengajarkan dan mendidik manusia.

Figur guru dituntut memiliki keahlian tertentu tidak hanya sebatas ia memiliki performance yang disyaratkan, tetapi lebih dari itu karena guru sudah dianggap pekerjaan profesi yang dipandang menjanjikan banyak orang, tidak hanya karena pekerjaannya yang mulia. Tetapi juga suatu pekerjaan yang mampu mengangkat harkat dan martabat manusia dikemudian hari. Pekerjaan menjadi guru juga menuntut seseorang itu memiliki kreteria dan syarat-syarat khusus, mengingat tidak semua orang mampu melakoni pekerjaan ini sebagaimana diinginkan.

Berdasarkan hasil penelitian, diperlukan guru-guru yang lebih profesional, guna melaksanakan proses pembelajaran yang diharapkan, terutama ketika proses pembelajaran di madrasah swasta Kota Jambi. Adanya kesadaran guru-guru untuk senantiasa meningkatkan profesionalisme guru sesuai dengan kompetensi yang dimilki juga sangat penting. Di samping itu pula menyadari dan memahami dari konsekwensi logis dari status guru bersertifikasi. Maka guru bersertifikasi mestinya juga dapat memperkuat komitmennya sebagai guru profesional sebagaimana tuntutan Undang-Undang Nomor 14 Tahun 2005. Ditengah derasnya arus perubahan yang setiap hari menuntut kesiapan guru dalam mengajar dimana pun ia berada. Lebih-lebih kesiapan guru-guru yang mendedikasikan pikiran, tenaga tercurahkan untuk mendidik dan membimbing anak-anak agar menjadi anak-anak yang mampu menjadi harapan tidak hanya untuk dirinya, orang tua, tetapi juga besar harapann adalah agar menjadi generasi yang mampu merubah sebuah peradaaban yang maju dan bermartabat.

Vol. 9 No. 1, Desember 2016

Madrasah homepage: http://ejournal.uin-malang.ac.id/index.php/madrasah/index 
Pemahamanm hakikat profesionalisme guru menjadi penting. Mengingat pemahaman menurut Prayitno (2008) juga mengandung pengertian mampu menyebutkan, mampu menguraikan, mampu menjawab, memiliki kemampuan mengaitkan dan memiliki kemampuan mencari data dan dan kemudian mengolahnya menjadi sumber kekuatan. Pemahaman juga menutut suatu sikap mental yang mampu memberi pengaruh (effect) nyata terhadap apa yang difahami. Profesionalisme guru-guru bersertifikasi dalam meningkatkan kualitas pembelajaran, terutama dimadrasah swasta khususnya di kota Jambi, diperlukan guna mendorong terciptanya iklim dan suasana pembelajaran yang kondusif dan efektif di madrasah. Sekolah atau madrasah yang efektif sangat dipengaruhi sejauh mana kualitas guru memahami karakteristik yang mendukung sekolah efektif. Reynolds dan Teddlie dalam Jamaluddin (2002:22-23) mengemukakkan Sembilan karakter sekolah yang efektif, yaitu: (1) kepemimpinan sekolah yang efektif, (2) guru dan proses pengajaran yang efektif, (3) terfoks dalam belajar, (4) menciptakan budaya (culture) sekolah yang positif, (5) ekspektasi yang tinggi terhadap prestasi dan tingkah laku, (6) menekankan tanggungjawab dan hak siswa, (7) memonitoring perkembangan dalam semua jenjang kelas, (8) pengembangan keahlian seluruh tenaga kependidikan, dan (9) melibatkan orang tua. Guru diharapkan dapat memberi perubahan ke arah yang lebih baik pada diri peserta didik dalam situasi pembelajaran.

Guru adalah aktor utama, yang turut serta mempengaruhi kualitas keberhasilan peserta didik. Guru juga, merupakan elemen terpenting dalam sebuah sistem pendidikan. Ia merupakan ujung tombak. Proses belajar siswa sangat di pengaruhi oleh bagaimana peserta didik memandang guru mereka. Kepribadian guru seperti memberi perhatian, hangat, dan suportif (memberi semangat), diyakini bisa memberi motivasi yang pada gilirannya akan meningkatkan prestasi peserta didik. Empati yang tepat seorang guru kepada siswanya membantu perkembangan prestasi akademik anak secara signifikan. Guru perlu membangun citra yang positif tentang dirinya jika ingin agar siswanya memberi respon dan bisa diajak bekerjasama dalam proses pembelajaran. Lebih jauh, rasa hormat dan kasih sayang yang ditunjukkan oleh seorang guru merupakan syarat utama kesuksesan siswa. Sebagaimana halnya orang dewasa, pemenuhan aspek psikologis siswa akan membuat mereka berusaha menunjukkan kemampuan terbaik yang bisa mereka lakukan dan secara otomatis akan meningkatkan prestasi mereka (Jamaluddin, 2002:36-37).

Profesionalisme guru, pada akhirnya akan melahirkan sosok dan figure guru yang memiliki karakter yang kuat dan dibanggakan tidak saja bagi diri guru yang bersangkutan, tetapi juga membawa suasana pencerahan di tengah terpaan dan sorotan tajam yang luar biasa bagi keberadaan guru di Indonesia, yang hari ini masih diliputi segudang problem begitu kompleksitas. Mulai dari proses rekrutmen mahasiswa calon tenaga guru, kualitas guru yang di hasilkan melalui LPTK atau institusi-institusi yang memproduk tenagatenaga pendidik, kompetensi yang dimiliki guru itu sendiri, rekrutmen penerimaan guru, dan kesenjangan antara guru pegawai negeri dan guru swasta, penempatan guru di kota dan di desa, kesemapatan memperoleh pendidikan yang lebih tinggi, persaingan untuk menjadi kepala sekolah/madrasah dan pengawas, kesenjangan antara guru di lingkungan Kementerian Pendidikan Nasional dan guru di bawah naungan Kementerian Departemen Agama, pelaksanaan Ujian Nasional (UN) masih ditemui kecurangan walaupun kecil, komersialisasi pendidikan melalui berbagai aktifitas di luar jam belajar, bisnis yang mengatas namakan pendidikan, penggunaan dan penyaluran dana BOS yang masih terindikasi salah sasaran, serta segudang persoalan-persoalan pendidikan lainnya.

Dengan status guru bersertifikasi, sudah seharusnya guru yang bersangkutan mampu menjadi guru profesional dan mampu menginternalisasikan nilai-nilai

Vol. 9 No. 1, Desember 2016

Madrasah homepage: http://ejournal.uin-malang.ac.id/index.php/madrasah/index 


\section{MADRASAH}

Jurnal Pendidikan dan Pembelajaran Dasar

p ISSN: 1979-5599 | e ISSN: 2502-194X

P a g e

profesionalisme sebagai sebuah jaminan akan masa depan anak-anak bangsa di kemudian hari. Bangsa yang maju kuat, kokoh, dan berperadaban serta berkarakter haruslah di mulai dari guru-guru yang professional dan berkarakter pula. Menyadari hal tersebut, adalah kewajiban semua guru-guru dan tenaga kependidikan, terus menerus meningkatkan kualitas diri dengan melakukan berbagai upaya peningkatkan profesionalisme guru bersertifikasi.

Guru adalah sosok yang mulia, dengan kemuliaannya itu tidak semua orang dapat/mampu menjadi figur guru. Begitu tingginya kedudukan guru dalam kehidupan manusia, menjadi sosok yang ditunggu kehadirannya di tengah kegelapan umat manusia. karena dengan adanya guru orang menjadi, tau, mau, terbiasa, bisa dan pandai, serta memiliki kepribadian yang diharapkan (Prayitno, 2009).

Menurut Fakry Gaffar (1999) menegaskan bahwa guru memegang peranan strategis terutama dalam upaya membentuk watak bangsa melalui pengembangan kepribadian dan nilai-nilai yang diinginkan. Dari dimensi tersebut, peranan guru sulit digantikan oleh yang lain, dipandang dari dimensi pembelajaran, peranan guru dalam masyarakat Indonesia tetap dominan sekalipun teknologi yang dapat dimanfaatkan dalam proses pembelajaran berkembang amat cepat. Hal ini disebabkan karena ada dimensi-dimensi proses pendidikan, atau lebih khusus lagi proses pembelajaran, yang diperankan oleh guru yang tidak dapat digantikan oleh teknologi. Sementara, menurut Mochtar Buchori (1994) berpendapat bahwa guru-guru kita dapat disamakan dengan pasukan tempur yang menentukan kemenangan atau kekalahan dalam peperangan.

Para birokrat pendidikan dalam pandangannya sebenarnya adalah pendukung semata-mata guru atau prajurit lapangan. Kalau birokrasi pendidikan benar-benar mendukung guru, maka pekerjaan mereka akan menjadi lebih ringan. Sebaliknya, kalui melalui tindakan-tindkan tertentu birokrasi pendidikan justru memberikan beban tambahan kepada guru, maka tugas guru-guru ini pun akan menjadi lebih berat. Dan kualitas pekerjaan mereka pun akan menurun. Selanjutnya, menurut Buchori (1999) ada lima faktor yang sangat mempengaruhi kualitas perilaku guru dalam melaksanakan tugasnya, yaitu: (1) jenis kewenangan (authority) yang benar-benar diserahkan kepada guru; (2) kualitas atasan yang mengawasi dan mengontrol prilaku guru; (3) kebebasan yang diberikan kepada guru, baik di dalam kelas maupun di luar kelas; (4) hubungan guru dengan murid-muridnya; (5) pengetahuan guru tentang dirinya sendiri dan kepercayaan terhadap dirinya sendiri.

Islam misalnya, menempatkan guru pada posisi yang mulia dan terhormat. Kemuliaan seorang guru terletak dari nilai-nilai kebaikan yang telah diberikan guru kepada orang yang memerlukan, terutama ilmu pengetahuan, dari manusia tidak tahu (tidak memiliki ilmu) sampai mereka kemudian tahu (memiliki ilmu). Dengan ilmu tersebut diharapkan manusia memiliki bekal kehidupannya. Menurut Daradjat (1992) mengemukakan bahwa di negara-negara timur sejak dahulu kala guru itu dihormati oleh masyarakat. Orang India dahulu, menganggap guru sebagai orang suci dan sakti. Di Jepang, guru disebut" shensei", artinya "yang lebih dahulu lahir", "yang lebih tua". Agama Islam sangat menghargai orang-orang yang berilmu pengetahuan (guru/ulama), sehingga hanya mereka sajalah yang pantas mencapai taraf ketinggian dan keutuhan hidup.

Allah SWT menegaskan, betapa pentingnya orang yang memilki ilmu pengetahuan, misalnya; Surah Al-Mujadalah ayat 11, Allah berfirman:

Vol. 9 No. 1, Desember 2016

Madrasah homepage: http://ejournal.uin-malang.ac.id/index.php/madrasah/index 


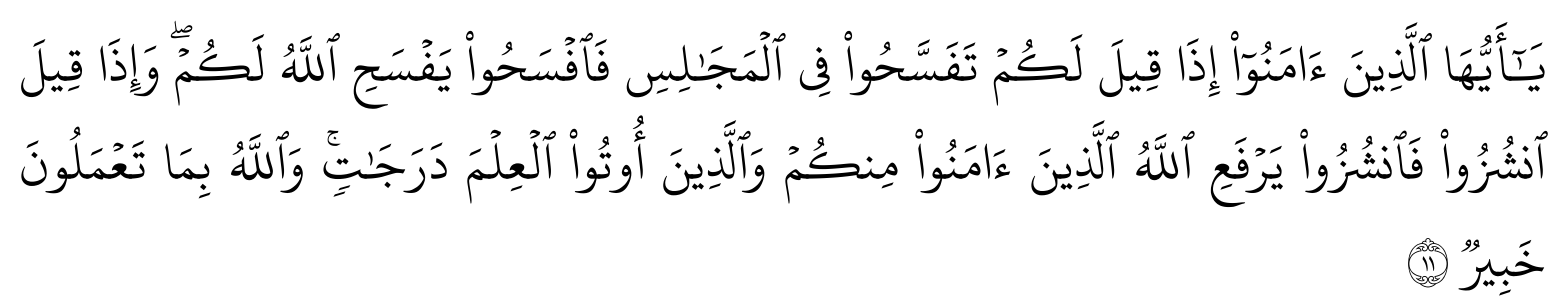

Artinya: "Hai orang-orang beriman apabila kamu dikatakan kepadamu: "Berlapanglapanglah dalam majlis", Maka lapangkanlah niscaya Allah akan memberi kelapangan untukmu. dan apabila dikatakan: "Berdirilah kamu", Maka berdirilah, niscaya Allah akan meninggikan orang-orang yang beriman di antaramu dan orang-orang yang diberi ilmu pengetahuan beberapa derajat. dan Allah Maha mengetahui apa yang kamu kerjakan"(QS. Al-Mujadalah (58:11).

Ayat di atas, mengingatkan kepada kita manusia, betapa luar biasa Allah SWT menempatkan orang yang beriman dan orang-orang yang berpengatahua luas lagi dalam diberi ketinggian derajat (penghormatan). Orang-orang yang memiliki ilmu pengetahuan luas tersebut tidak serta merta dengan sendirinya didapat/diperoleh, ia di tuntun dan dibimbing salah satunya oleh guru (ulama). Oleh karena itu keberadaan guru (orang-orang alim) sangatlah menjadi perhatian bahkan diagung-agungkan karena kedalaman ilmunya. Orang bijak seperti Imam Al-Ghazali (1995) berkata guru merupakan pelita segala zaman. Orang yang hidup bersamanya akan memperoleh pancaran nur keilmiahan. Andaikata dunia tidak ada guru, niscaya anusia seperti binatang, sebab guru selalu berupaya mengeluarkan manusia dari sifat kebinatangan kepada sifat insaniyah.

Kedudukan orang yang memiliki ilmu pengetahuan dalam Islam sangatlah dihargai. Al-Ghazali (1995) menyatakan bahwa orang alim yang bersedia mengamalkan pengetahuannya adalah orang besar di semua kerajaan langit. Dia seperti matahari yang menerangi alam, mempunyai cahaya dalam dirinya, seperti minyak wangi yang mengharumi orang lain karena ia memang wangi.

Mochtar Buchori (1994) menjelaskan bahwa, guru yag baik ialah guru yang mampu melaksanakan inspiring teaching, yaitu guru yang melalui kegiatan mengajarnya mampu mengilhami murid-muridnya. Melalui kegiatan mengajar yang memberikan ilham ini guru yang baik menghidupakan gagasan-gagasan yang besae, keinginan yang besar pada muridnya. Kita ketahui bersama bahwa kemampuan seperti ini tidak datang dengan sendirinya. Kemampuan ini harus dikembangkan, harus ditumbuhkan sedidkit-demi sedikit. Dalam Peraturan Pemerintah (PP) nomor 74 tahun 2008 tentang Guru, sebutan guru mencakup: (1) guru itu sendiri, baik guru kelas, guru bidang studi, maupunguru bimbingan dan konseling atau guru bimbingan karir; (2) guru dengan tugas tambahan sebagai kepala sekolah; dan (3) guru dalam jabatan pengawas. Selanjutnya untuk memenuhi kreteria profesional, guru harus menjalani suatu proses menuju derajat profesional yang sesungguhnya secara terus menerus, termasuk kompetensi mengelola kelas. Di dalam Peraturan pemerintah nomor 74 tahun 2008 itu juga dibedakan antara pembinaan dan pengembangan kompetensi guru yang belum dan yang sudah berkualifikasi S-1 atau D-IV (Danim, 2010).

Selanjutnya, menurut Danim (2010) pendidikan, pelatihan, dan pengembangan merupakan proses yang ditempuh oleh guru pada saat menjalani tugas-tugas kedinasan. Kegiatan ini diorganisasikan secara beragam dan berspektrum luas dengan tujuan untuk

Vol. 9 No. 1, Desember 2016

Madrasah homepage: http://ejournal.uin-malang.ac.id/index.php/madrasah/index 


\section{MADRASAH}

Jurnal Pendidikan dan Pembelajaran Dasar

p ISSN: 1979-5599 | e ISSN: 2502-194X

P a g e

meningkatkan kompetensi, keterampilan, sikap, pemahaman, dan performansi yang dibutuhkan oleh guru saat ini dan di masa mendatang. Alasan esensial diperlukannya pembinaan dan pengembangan guru adalah karakteristik tugas yang terus berkembang seirama dengan perkembangan ilmu pengetahuan dan teknologi, di samping reformasi internal pedidikan itu sendiri. Secara umum kegiatan ini dibedakan menjadi dua jenis, yaitu metode-metode praktis (on the jobtraining and development) dan teknik-teknik presentasi atau metode-metode simulasi (off-the jobtraining and development). Metodemetode praktis terdiri dari pelatihan instruksi pekerjaan, magang, intensif, asistensif atau penugasan sementara, rotasi jabatan, perencanaan karir pribadi, pelatihan eksekutif, asisten kepenyeliaan (pengarahan, konseling, dan monitoring). Teknik-teknik presentasi informasi dan metode-metode simulasi meliputi kursus formal, pelatihan oleh diri sendiri (pengajaran berprogama, membaca, kursus korespondensi), pelatihan oleh pihak lain (ceramah dan kursus kelas), simulasi (pelatihan oleh pelatih khusus, management games, pusat-pusat asesment), bermain peran, presentasi video, pelatihan laboratoris, dan metode konferensi.

Sagala (2006) menyatakan bahwa profesionalisme guru belum selesai dengan hanya memberikannya lisensi mengajar setelah mereka berhasil menamatkan pendidikannya di LPTK, hal yang demikian baru aspek formal, karena kualifikasi formal ini masih perlu dijiwai dengan kualifikasi riil yang hanya mungkin diwujudkan dalam praktek yang menunjukkan keterampilan teknik serta didukung sikap kepribadian yang mantap.

Pembinaan dan pengembangan profesi guru berarti meningkatkan kualitas dan peningkatan pelayanan, dalam pembinaan dan pengembanagn karier tenaga profesional kependidikan, khususnya guru masih memerlukan pemikiran serta pengkajian. Pembinaan dan pengembangan profesi guru yang dapat dilakukan adalah menyempurnakan pengembangan sistem yang terus menerus, maka program harus dilalui adalah pengembangan profesional berbagai tenagakependidikan dan guru melalui program pre service. Program ini mempersiapkan calon tenaga kependidikan dan guru melalui jalur penddidikan formal.

\section{SIMPULAN}

Berdasarkan kajian analis dan pembahasan tentang "Komitmen Profesionalisme Guru Bersertifikasi Mengajar di Madrasah Swasta Kota Jambi), dapat ditarik beberapa kesimpulan, sebagai berikut: (1) Profesionalisme guru pegawai negeri sipil (PNS) bersertifikasi yang mengajar di madrasah Kota Jambi menyadari pentingnya komitmen, tanggung-jawab dan dedikasi yang tinggi, (2) Upaya-upaya peningkatan profesionalisme guru pegawai negeri sipil (PNS) bersertifikasi dalam rangka meningkatkan kualitas pembelajaran di madrasah swasta Kota Jambi belum sepenuhnya berlangsung dengan baik. Pembinaan melalui pendidikan dan latihan (Diklat) belum tersosialisasi dengan baik dan kegiatan pendidikan tambahan seperti S2 masih bersifat insidental. MGMP, KKG dan KKKS misalnya belum menjadi agenda rutin kepala madrasah dan guru-guru, serta (3) Hambatan bersifat koordinasi antar stakeholder menjadi problem utama dalam peningkatan profesionalisme guru bersertifikasi. Pendanaan menjadi alasan klasik para stakeholder dalam menentukan kebijakan. Sehingga terkesan, ketiadaan anggaran menjadi pembenaran kurangnya pembinaan kompetensi guru bersertifikasi.

Vol. 9 No. 1, Desember 2016

Madrasah homepage: http://ejournal.uin-malang.ac.id/index.php/madrasah/index 


\section{REFERENSI}

Al. Gazhali. (1995). Kemulian Menuntut Ilmu.Jakarta: Bulan Bintang

Alexander, R. (2001).Culture E Pedagogy. Oxford: Blackwell Publishing Ltd

Bogdan, R. E. dan Taylor J. S. (1993). Kualitatif Dasar-Dasar Penelitian. (terjemahan A. Khosim Afandi). Surabaya: Usaha Nasional

Bogdan, R. E. dan Bikland, Knopp.S. (1982). Qualitative Research For Education. Bostor : Allyn an Bacon Inc

Daradjat, Z. (1978). Kepribadian Guru. Jakarta: Metro Pos

Depdikbud. (1992). Himpunan Peraturan Perundang-Undangan Rebublik Indonesia. Jakarta: Depdikbud

Denzin, N. K \& Lincoln, Y.S. (1994). Handbook of Qualitatif Research. New York: Sage Publication, Inc

Jamaluddin. (2002). Pembelajaran yang Efektif Faktor-Faktor yang mempengaruhi Prestasi Siswa. Jakarta Dirjen Bimbaga Depag RI

Lincoln, Y. V \& Guba, E. G. (1985). Naturalistic Inguiry. Beverly Hill Sage Publications

Mochtar Buchari. (1994). Ilmu Pendidikan dan Praktek Pendidikan dalam Renungan. Jakarta: IKIP Muhammadiyah Jakarta Press

Novak, Joseph D. (1986). A Theory of Education.London: Cornell University Press

Nyayu Khodijah. (2013). Kinerja Guru Madrasah dan Guru pendidikan Agama Islam Pasca Sertifikasi di Sumatera Selatan, dalam Cakrawala Pendidikan, XXXII (1)

Prayitno. (1999). Perspektif Tenaga Kependidikan Sekolah Menengah. (Makalah). Padang: IKIP Padang

. (2005). Sosok Keilmuan Ilmu Pendidikan. Padang: Fakultas Ilmu Pendidikan UNP . (2005). Peta Keilmuan Pendidikan. Padang Fakultas Ilmu Pendidikan UNP . (2009). Pendidikan Dasar Teori dan Praksis (jilid I dan II) Padang: Universitas Negeri Padang Press

Soetjipto Dan Raflis Kosasi. (2009). Profesi Keguruan.Jakarta: Rineka Cipta

Sudarwan Danim. (2010). Profesionalisasi dan Etika Profesi Guru. Bandung: Alfabet

Syaiful Sagala. (2006). Administrasi Pendidikan Komtemporer. Bandung: Alfabeta

Spradley, J. P. (1980). Participan Observation.United state of America: Rinehart and Winston - (1997). Metode Etnografi (terjemahan Misbah Elizabeth). Yogyakarta: Tiara Wacana

Tilaar. H.A.R. (2002). Perubahan Sosial dan Pendidikan Pengantar Pedagogik Transformatif untuk Indonesia.Jakarta: Gramedia 2008. Kebijakan Pendidikan Pengantar untuk Memahami Kebijakan Pendidikan sebagai Kebijakan Publik. Yogyakarta: Pustaka Pelajar

Undang-undang Sistem Penddikan Nasional Nomor 20 Tahun 2003

Vol. 9 No. 1, Desember 2016

Madrasah homepage: http://ejournal.uin-malang.ac.id/index.php/madrasah/index 